\title{
Heracliteïsche Ethiek : omgaan met de Soft Impacts van Technologie.
}

Citation for published version (APA):

Swierstra, T. E. (2011). Heracliteïsche Ethiek : omgaan met de Soft Impacts van Technologie. Maastricht University. https://doi.org/10.26481/spe.20110916ts

Document status and date:

Published: 16/09/2011

DOI:

$10.26481 /$ spe.20110916ts

Document Version:

Publisher's PDF, also known as Version of record

\section{Please check the document version of this publication:}

- A submitted manuscript is the version of the article upon submission and before peer-review. There can be important differences between the submitted version and the official published version of record.

People interested in the research are advised to contact the author for the final version of the publication, or visit the DOI to the publisher's website.

- The final author version and the galley proof are versions of the publication after peer review.

- The final published version features the final layout of the paper including the volume, issue and page numbers.

Link to publication

\footnotetext{
General rights rights.

- You may freely distribute the URL identifying the publication in the public portal. please follow below link for the End User Agreement:

www.umlib.nl/taverne-license

Take down policy

If you believe that this document breaches copyright please contact us at:

repository@maastrichtuniversity.nl

providing details and we will investigate your claim.
}

Copyright and moral rights for the publications made accessible in the public portal are retained by the authors and/or other copyright owners and it is a condition of accessing publications that users recognise and abide by the legal requirements associated with these

- Users may download and print one copy of any publication from the public portal for the purpose of private study or research.

- You may not further distribute the material or use it for any profit-making activity or commercial gain

If the publication is distributed under the terms of Article $25 \mathrm{fa}$ of the Dutch Copyright Act, indicated by the "Taverne" license above, 


\section{Heracliteïsche ethiek. Omgaan met de soft impacts van technologie}

Inauguratie van Prof.dr. Tsjalling Swierstra, benoemd tot hoogleraar

Wijsbegeerte in de Faculteit der Cultuur- en Maatschappijwetenschappen

op vrijdag 16 september 2011 om 16.45 uur in

de Aula van de Universiteit Maastricht, Minderbroedersberg 4-6 te Maastricht. 


\begin{abstract}
Mijnheer de Rector,
Lieve familie en vrienden,

Beste collega's en bekenden,

Geachte overige aanwezigen,
\end{abstract}

\title{
$\underline{\text { Inleiding }}$
}

Als ik vraag hoe veel hoofdzonden er zijn, zegt $U$ natuurlijk ... zeven. Dan zit $U$ er echter precies zeven naast. Niet omdat hoogmoed, lust, luiheid, geen doodzonden meer zouden zijn - dat mocht $U$ willen - maar omdat er zeven nieuwe bij zijn gekomen. $U$ gaat tegenwoordig, tenzij $U$ op tijd berouw toont, ook naar de hel voor de volgende zonden:

1. Genetische modificatie

2. Experimenten op mensen

3. Milieuvervuiling

4. Drugsgebruik

5. Sociale onrechtvaardigheid veroorzaken

6. Armoe veroorzaken

7. Obscene rijkdom.

Aldus op 9 maart 2008 bekend gemaakt door L'Osservatore Romano. Blijkbaar is Marx' stelling dat 'Religie opium van het volk [is]' het Vaticaan ontgaan, en is zij inmiddels armlastig genoeg om ook die laatste zonde veilig te kunnen opvoeren.

Maar interessanter is, dat de eerste vier van deze nieuwe zonden direct te maken hebben met moderne wetenschap en technologie, en de andere drie minstens indirect. Als zelfs het Vaticaan, toch geen instituut dat bekend staat om haar vermetele vernieuwingsdrift, besluit tot zo'n radicale morele update, dan mogen we concluderen dat technologische innovatie blijkbaar noopt tot morele 
innovatie. Hoe die invloed van de techniek op de moraal te begrijpen? Hoe daarmee om te gaan?

$\underline{\text { Invloed }}$

Kijkt U eerst eens naar deze grafiek:

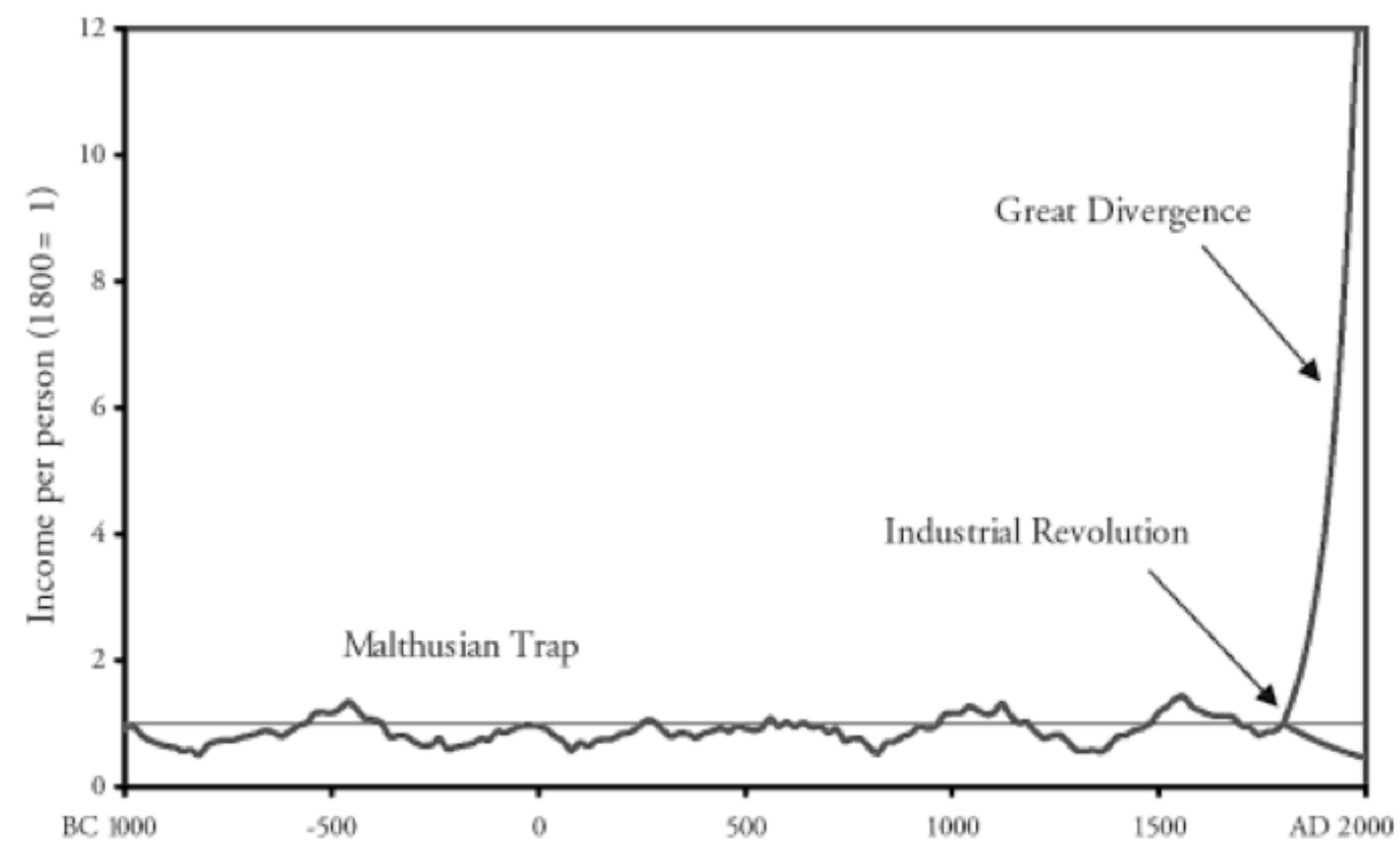

Figure I.I World economic history in one picture. Incomes rose sharply in many countries after 1800 but declined in others.

[bron: Gregory Clark (2008). A Farewell to Alms: A Brief Economic History of the World.

Princeton, New-Jersey: Princeton University Press]

Die muur waar je rechts tegenaan loopt, is de mondiale welvaartstijging sinds 1800. Tot die tijd maakte het voor je inkomen, gezondheid en levensverwachting weinig uit of je in Patagonië, Kameroen, Peking, New York of Leiden woonde. Maar de Industriële Revolutie verandert dat radicaal: eerst in het Westen, later ook elders. De Industriële Revolutie is niets anders dan de snelle opmars van de techniek binnen de economie, maar ook binnen de nationale en internationale politiek, de oorlogsvoering, het beleid, het onderwijs, de zorg, de wetenschap, de kunst, het recht, de vrije tijd, de communicatie, de liefde, het gezin, en de moraal. 
De moderne wereld is de wereld waarin techniek alles verandert. [Zie bijvoorbeeld: Misa, T., and A. Brey, eds. 2003. Modernity and technology. Cambridge, MA: MIT Press.

\section{Gebrek aan aandacht: hard impacts}

Toch denken we tegenwoordig vaak nog over technologie zoals rijke mensen vroeger dachten over slaven en bedienden, namelijk: zo weinig mogelijk. Slaven, bedienden en apparaten moeten gewoon hun werk doen. Als ze toch een keer aandacht vragen, is er dus per definitie iets mis. Niemand zei vroeger: 'Hé een slaaf.' Maar een slaaf die zijn middelvinger opstak, ja, die zal ongetwijfeld de nodige aandacht hebben gekregen. En zo zeggen we tegenwoordig niet: ' $\mathrm{He}$, een verwarming.' Maar: 'He, de verwarming weigert dienst.'

We neigen ertoe de techniek te negeren, maar net als vroeger bij slaven en bedienden blijven we toch ook waakzaam. Als je vroeger namelijk niet oppaste, roerde de butler gif door je wijn, stak de tuinman een schaar in je rug, of probeerden de slaven zelfs de boel over te nemen. Over techniek denken we in identieke termen: handig en nodig, maar wel oppassen dat zij jou of je omgeving niet vergiftigt, dat ze niet achter je rug ontploft, en dat ze de boel niet van ons overneemt. Het probleem is dan ook nog steeds hetzelfde, namelijk: Hoe blijven we de baas?! Techniek moet onze bevelen uitvoeren, maar mag omgekeerd geen macht over ons hebben. En dus gaat de meeste aandacht op aan wat ik de hard impacts van technologie noem. Op weekdagen maken we ons zorgen over de gezondheidsrisico's, veiligheidsrisico's en milieurisico's van techniek, en in het weekend rusten we uit bij een fijne, zij het geheel vrijblijvende, preek over dat die techniek nu toch wel heel erg slim dreigt te worden en oh oh hoe zal dat in de toekomst aflopen.

Maar wat nou als techniek ons niet vergiftigt, niet ontploft, en de boel niet overneemt? Verdient zij dan geen aandacht? Even terug naar de slaven. Rijke Romeinen hadden er geen probleem mee te vrijen terwijl er slaven omheen stonden. Je schreef een traktaat over iustitia terwijl een slaaf je intussen koelte 
toewapperde. Slaven en meesters verkeerden permanent in elkaars nabijheid. Die moeten elkaar hebben gevormd, als kiezels in een beekbedding. Ze veronderstellen en definiëren elkaar. Simpelweg door er te zijn, beïnvloedt de slaaf de zelfopvatting, het karakter, de normen, de waarden, de vaardigheden en de behoeften van de meester. Mijn filosofische collega's waren daar destijds helaas volstrekt niet in geïnteresseerd. Alleen al de vraag hoe de slaaf de meester vormde, was absurd en schaamteloos. Hun arrogante fout wil ik nu niet herhalen in het geval van de techniek waarmee wij tegenwoordig ons leven delen.

De hard impacts van techniek, zijn natuurlijk belangrijk. Maar in het leven van alledag worden we niet het meest bepaald door ontploffende, vergiftigende of de boel overnemende technologie. Wel door techniek die op nauwelijks zichtbare wijze vorm geeft aan onze manieren van doen, aan onze relaties, aan onze normen, waarden, rechten, plichten, verwachtingen en verlangens. Denk aan hoe de pil de sekseverhoudingen heeft veranderd; hoe de computer het werk heeft veranderd; hoe de mobiele telefoon sociale relaties heeft veranderd. Dit soort gevolgen van technologie noem ik soft impacts.

Om daar goed mee om te gaan, moeten we de relatie tussen mens en techniek anders begrijpen. De slaven en dienstmeisjes die zwijgend deden wat hun meerderen bevalen, geven inmiddels als medeburgers zelf hun mening. Ook van de techniek moeten we accepteren dat zij een eigen stem heeft. Geen overheersingrelatie, maar eerder een huwelijk waarin partners elkaar vormen. Nou is niet elke huwelijk even geslaagd. Sommige echtgenoten vormen elkaar vooral door aan elkaar te slijten. In heel algemene termen kunt $U$ mijn onderzoek begrijpen als relatietherapie voor mens en techniek, waarbij ik mij met name richt op de wisselwerking tussen technologie en moraal.

De invloed van techniek op moraal 
Ik presenteer vandaag een model om de invloed van de technologie op de moraal te analyseren. Ik onderscheid tussen handelingsmoraal - of ethiek; ik gebruik de woorden vandaag door elkaar - en de moraal - of ethiek - van het goede leven.

Ik ga nu eerst in op de handelingsethiek. Moreel handelen betekent dat je rekening houdt met degenen die de gevolgen van jouw keuzes dragen. Die anderen noemen we 'stakeholders'. Om te bepalen hoe je moet handelen, moeten we dus weten: wat zijn de gevolgen van ons handelen, en wie zijn de stakeholders?

Ik spreek van technomorele verandering wanneer nieuwe techniek bestaande antwoorden op die beide vragen aan het wankelen brengt. Dat kan Techniek op twee manieren doen: zij kan de moraal veranderen door ons stakeholders en handelingsgevolgen anders te laten waarnemen, of door onze praktische mogelijkheden te veranderen om iets voor die stakeholders en aan die gevolgen te doen.

In schemavorm ziet dit er dan als volgt uit:

\begin{tabular}{|l|l|l|}
\hline Handelingsethiek & Andere waarneming & Andere handelingsoptie(s) \\
\hline Stakeholders & 1: (on)zichtbaarheid & 2: 'pech' wordt 'onrecht' \\
\hline Gevolgen & 3: vooruitzien & $\begin{array}{l}\text { 4: macht en } \\
\text { verantwoordelijkheid }\end{array}$ \\
\hline
\end{tabular}

Ik zal het verduidelijken.

\section{1) (on)zichtbaarheid}

Voor ons morele oordeel maakt het veel uit met wie we vinden dat we rekening moeten houden -met mijn familie, het dorp, de wereld, ook met dieren? Technologie heeft daar grote invloed op. Het is gemakkelijker om iemand met een vliegtuigbom te vermoorden dan met een mes, omdat de bom de 
slachtoffers onzichtbaar maakt. Een omgekeerd voorbeeld: niemand vond een bevruchte eicel beschermwaardig voordat de microscoop ons wees op het bestaan daarvan. Als je weet dat dit type technomorele verandering bestaat, kun je dat inzicht gebruiken om de gevolgen van nieuwe, onbekende techniek te verkennen. Momenteel worden nano-zilverdeeltjes gebruikt in sokken, tegen zweetgeur. Met collega's uit Twente hadden we bedacht: Wat nu als iemand die deeltjes in luiers stopt? Klinkt slim, nietwaar? Maar baby's en demente meneren hebben soms geen andere manier om hun nood kenbaar te maken dan door te stinken. Nanoluiers maken zulke stakeholders dus eigenlijk onzichtbaar. Misschien dus toch niet zo'n slim idee.

\section{2) 'pech' wordt 'onrecht'}

Techniek wijst ons niet alleen op nieuwe stakeholders door hen zichtbaar te maken, maar ook doordat we nu iets voor ze kunnen doen. Als verschillen tussen mensen niet verholpen kunnen worden, vallen ze buiten het bereik van de moraal. Is het oneerlijk dat wanneer twee sporters even hard trainen, degene met het beste lichaam wint? Is het oneerlijk dat mensen met minder talent ook minder kansen hebben? Momenteel vinden we dat wel sneu, maar niet oneerlijk. We kunnen er immers niets aan veranderen. Maar wat als nieuwe techniek, bijvoorbeeld doping, zulke verschillen wel kan verhelpen? Op dat moment houden natuurlijke verschillen op natuurlijk te zijn,en verandert Pech in Onrecht. En waar onrecht is, zijn stakeholders die rechten claimen en ons op onze plichten wijzen. Kortom: techniek kan nieuwe stakeholders creëren.

\section{3) vooruitzien}

Verleggen we onze aandacht van de stakeholders naar de gevolgen van ons handelen. Nieuwe techniek kan onze waarneming daarvan veranderen. In IJsland is onlangs voorgesteld dat je sigaretten alleen nog op doktersrecept kunt krijgen. Nou, dat is niets nieuws. 


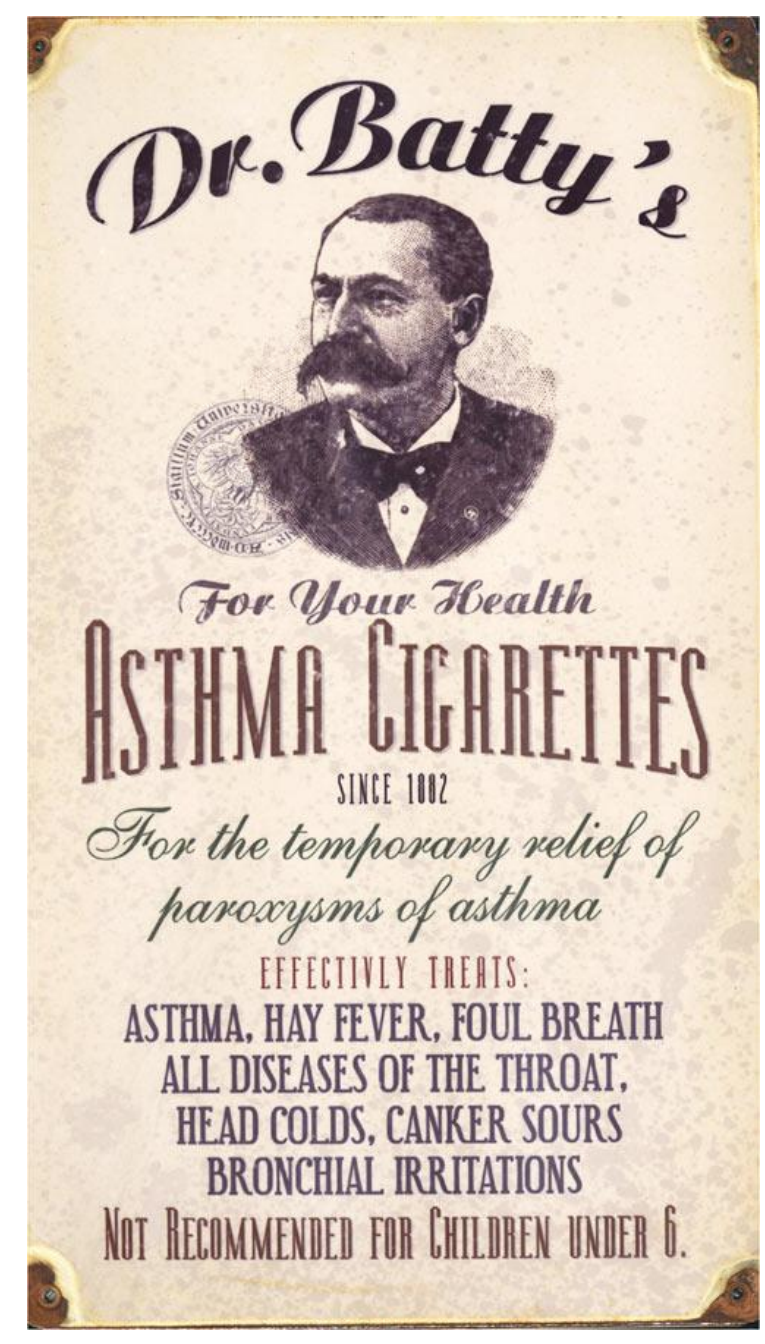

[Bron: www.http://poculum.tumblr.com/post/6339866438/asthma-cigarettes-not-suitable-forchildren-under]

Let wel: niet geschikt voor kinderen onder de 6. Tegenwoordig is het immoreel om astma patientjes van boven de 6 een sigaret in het hoestende mondje te duwen. Allerlei technologie, van röntgen apparaten tot computers, heeft ons namelijk bewust gemaakt van de gevolgen van roken. Daardoor is ons morele oordeel over het aanbieden van sigaretten veranderd.

Ook met betrekking tot de liefde ligt overigens nog een heel techniekfilosofisch onderzoeksterrein braak. 


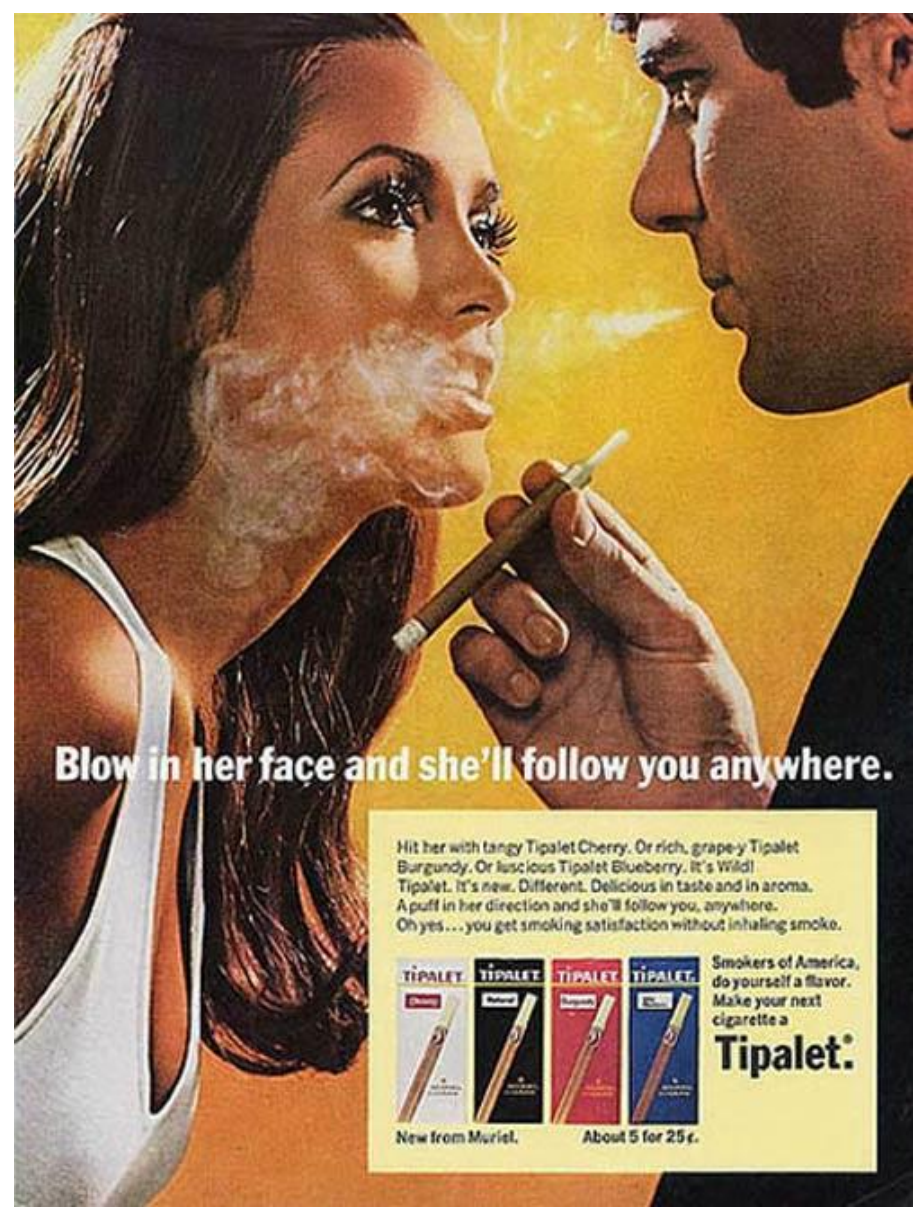

[Bron: http://adsoftheworld.com/blog/chris/2007/may/14/the_good_old_days]

\section{4) macht komt met verantwoordelijkheid}

Dat we de gevolgen van ons handelen beter of anders waarnemen, betekent niet altijd dat we er ook meer greep op hebben. We weten dat ons gedrag bijdraagt aan de opwarming van het klimaat. Maar zolang het praktisch gesproken heel moeilijk is dat gedrag te veranderen, legt die kennis weinig moreel gewicht in de schaal. Dat gewicht groeit echter, naarmate er meer duurzame techniek beschikbaar komt. Hoe gemakkelijker het wordt om het goede te doen, des te verwijtbaarder wordt het om dat dan toch niet te doen. Kunnen en moeten hangen dus samen. Als je niets kan, hoeft je niets. Maar als je veel kunt- bijvoorbeeld dankzij nieuwe technologie - , neemt je verantwoordelijkheid evenredig toe. 
De gegroeide rol van de technologie zien we terug in de geleidelijke verschuiving van plichtsethiek vroeger naar gevolgenethiek nu. Als je weinig greep op de wereld hebt, willen goede bedoelingen nogal eens uitmonden in slechte gevolgen. De mens wikt, maar God beschikt. In zo'n situatie is het verdedigbaar om te zeggen: 'Ik doe mijn plicht, maar laat de verantwoordelijkheid voor de gevolgen over aan God.' Maar als techniek onze greep op de wereld nu verstevigt, dan is de vraag niet langer: 'Deed je je plicht?' maar: 'Heb je het al mogelijke gedaan om bepaalde gevolgen te vermijden of juist te realiseren?'

Prenatale genetische diagnostiek, bijvoorbeeld, maakt het mogelijk ernstig gehandicapte kinderen niet geboren te laten worden. Tegenstanders zeggen: ik vrij, God beschikt, en ik draag de gevolgen, hopelijk met wat hulp van God. Voorstanders zeggen: ik vrij, de techniek geeft mij greep op de gevolgen, en dan is het onverantwoordelijk om toch een zwaar gehandicapt kind geboren te laten worden.

Okay, Genoeg over de handelingsethiek, over naar de ethiek van het goede, mooie, bewonderenswaardige, betekenisvolle leven. Hier ligt de focus niet op de gevolgen van ons handelen voor anderen, maar op ons 'zelf'. Wat is dat zelf, en wat valt ervan te maken? Elke opvatting van het goede leven verwijst daarbij naar de omgeving waarbinnen dat goede leven moet worden geleid. Ook bij de levensethiek onderscheid ik daarom twee variabelen: enerzijds het zelf, anderzijds de - natuurlijke, sociale, of metafysische - wereld waarbinnen dat 'zelf' goed probeert te leven.

In schemavorm ziet dat er dus zo uit:

\begin{tabular}{|l|l|l|}
\hline Ethiek vh goede leven & Andere waarneming & Andere handelingsoptie(s) \\
\hline Zelf & 5. Zelfkennis & 6. Zelfstilering \\
\hline Wereld & 7. Orde of Chaos & 8. Lot of Wil \\
\hline
\end{tabular}


Deze vier variabelen vormen als het ware de vier 'ophangpunten' van een opvatting van het goede leven. Zo'n opvatting wordt namelijk geïnformeerd door hoe we onszelf zien en door wat we denken te kunnen, maar ook door hoe we de wereld zien en door hoe veel greep we op die wereld menen te hebben. Bijvoorbeeld: Als ik mijzelf zie als begiftigd met een onsterfelijke ziel, dan is er een goede kans dat ik mij aan de zorg van die ziel wijd, dat ik geloof dat mensen het hoogtepunt van de schepping zijn, en dat het mijn taak is die scheppingsorde te helpen beschermen. Ervaar ik daarentegen de wereld als strijd, dan zie ik mijzelf waarschijnlijk als vechter, dan probeer ik sterker te worden, en ben ik uit op winnen.

Ik loop de vier vakken weer langs.

\section{Zelfkennis}

Aan de basis van elke levensethiek staat het gebod van het orakel van Delphi: Ken Uzelve. Maar nieuwe techniek kan veranderen hoe we ons 'zelf' kennen. Voor zelfkennis zijn moderne mensen niet langer, zoals de oude Grieken, exclusief aangewezen op introspectie of op de meningen van anderen. Moderne diagnostische technieken claimen Uw lichaam beter te kennen dan $U$ zelf en hersenscans leggen Uw brein open. Die nieuwe informatie is soms verwarrend. $U$ dacht gezond te zijn, maar het apparaat zegt dat $U$ eigenlijk al ziek bent. $U$ dacht hetero te zijn, maar Uw hersenscan zegt echt iets anders. Introspectie moet vanaf nu concurreren met door techniek gegenereerde zelfkennis.

\section{Zelfstilering}

Dat 'zelf' kun je niet alleen kennen, maar ook vormen. Mensen gaan dan bijvoorbeeld sporten, gezond eten, afzien van seks, of juist jagen op seks, streven naar onafhankelijkheid, of juist naar vriendschap en gebondenheid. Dit is het domein van de askèsis: de zelfoefening of -stilering. Een speerpunt in de askesis is het ontwikkelen van wezenlijke vaardigheden. Zonder die vaardigheden, geen goed leven. 
Maar als technologie ons werk uit handen neemt, verleren we zulke vaardigheden dan niet? Plato waarschuwde al dat het schrift - ja dat is ook techniek - ons geheugen aantastte. Tegenwoordig wordt de ANWB alarm centrale gebeld met” 'Mijn TomTom is stuk!' 'We sturen hulp, meneer, waar zit U?' 'Hoe moet ik dat weten?! Mijn TomTom is toch stuk!'

Ander speerpunt van de askèsis is het managen VAN onze behoeften. Behoeften zijn een bron van voortdurend terugkerende frustratie. Het verlangen is een onverzadigbare tiran. De meeste behoeften kun je niet blijvend bevredigen - morgen heb je weer dorst. En als het wel lukt, worden we toch niet gelukkig. 'Het bezit van de zaak is het eind van het vermaak', zo doceert menig tegeltje. Bevrediging van oude behoeften leidt slechts tot nieuwe. Netto schiet je niets op. Kortom: geen goed leven zonder matiging. Tenzij het natuurlijk gaat om je verlangen naar Waarheid of God. Daar is heel veel van terwijl je er toch nooit genoeg van schijnt te krijgen.

Techniek heeft de neiging deze traditionele visie op behoeften te ondermijnen. Is matiging niet achterhaald in een wereld van massaproductie en consumptie? Techniek schept permanent nieuwe behoeften. Nieuwe diagnostische technieken scheppen bijvoorbeeld bij gezonde mensen nieuwe behoeften aan medicijnen die moeten voorkomen dat ze misschien later ziek worden. En wist $U$ twee jaar geleden al dat $U$ echt niet zonder I-pad kon?

\section{Orde of Chaos}

Het kennen en vormgeven van het zelf staat niet los van iemands wereldbeeld. Biedt de wereld ons een 'thuis' waarbinnen we ons op onze plaats weten? Of vormt ze het chaotische decor tegen de achtergrond waarvan wij ons leven invullen: vrij, onbepaald, aan niets of niemand gehoorzaamheid verschuldigd, maar misschien ook richtingloos - en volgens sommigen: wezenloos.

Ook wereldbeelden zijn niet immuun voor techniek. Als de zon om de aarde draait, draait zij ook om mij. Als dan Galileï met zijn lange telescoop komt en dit sprookje uit blaast, verlies ook ik mijn plaats in het centrum van het Heelal. Of: de synthetische bioloog begrijpt de natuur vooral als een samenraapsel van 
maar matig efficiënte oplossingen. Als er al design achter zit, dan zeker geen erg 'intelligent design'. Maar dan geldt dat ook voor mijn lichaam en brein.

\section{Lot of Wil}

Als we nadenken over het goede leven, is ook van belang in hoeverre we binnen die wereld doelgericht menen te kunnen opereren. Als de wereld zich regelmatig plooit naar jouw hand, dan loont het om plannen te maken voor de toekomst. Maar als de wereld zich juist niets van jou aantrekt, dan zul je eerder op het idee komen om je uit die wereld terug trekken, of om juist helemaal bij de dag te gaan leven.

Technologie is uiteraard juist op dit punt van enorme invloed geweest. De Verlichting en de Industriële Revolutie hebben een enorme boost gegeven aan het maakbaarheidgeloof. We zijn niet uitgeleverd aan het blinde Noodlot, maar leggen met hulp van wetenschap en techniek de wereld onze Wil op.

De ironie is uiteraard dat techniek inmiddels zelf hulpeloosheid en fatalisme oproept: de wereld is zo complex geworden dat velen wanhopen waar de knoppen en hendels zitten. De techniek die ons zou bevrijden van het Lot, wordt nu zelf als Lot ervaren.

\section{$\underline{\text { Heracliteïsche ethiek }}$}

In de kluwen van technologie en moraal zit dus wel enig systeem. Techniek is geen slaaf, maar een partner die ons, tot in de diepste krochten van onze ziel, mee-bepaalt. En dat gebeurt voortdurend opnieuw. Onze technologische cultuur wordt immers gedefinieerd door haar dynamiek. Een liberaal Kamerlid zei het ooit mooi:

"Wat is tegenwoordig nieuw? De radicalen van voor tien jaren zijn de conservatieven van thans. Met woeste hand wordt het gebouw, dat pas is opgebouwd, weer afgebroken. Rusteloze beweging overal en in alles." 
[Geciteerd in Van der Woud (2006). Een nieuwe wereld. Het ontstaan van het moderne Nederland. Amsterdam: Bert Bakker. p.106]

Dat was Goeman Borgesius, in 1876. Het enige blijvende is de verandering.

We moeten de invloed van de techniek op de moraal niet lineair opvatten. Het is niet: " $U$ draait, wij vragen." Technische innovatie dwingt nooit één bepaalde morele innovatie af, maar schept onzekerheid, zoeken, controverse, strijd, met altijd meerdere mogelijke uitkomsten.

Ik wil mij de komende jaren verder verdiepen in deze dynamische relatie tussen techniek en moraal. Dat is pionierswerk, omdat de ethiek van oudsher weinig op heeft met morele verandering. Dat riekt namelijk naar moreel relativisme. Veel ethici blijven erfgenamen van Plato, die 'vast' gelijkstelde aan 'werkelijk', en 'veranderlijk' gelijk stelde aan 'schijn'. Moraal wordt door hen het liefst voorgesteld als in rust, met harmonie tussen alle normen en waarden. Meningen over het Goede mogen veranderen, niet het Goede zelf. Geconfronteerd met morele verandering duiken deze ethici daarom de diepte in, op zoek naar fundamenten en axioma's, om zo het tijdloze koren van het tijdelijke kaf te scheiden.

Maar niet alle ethici. Mijn eigen opvatting is een cocktail van John Dewey's pragmatisme en Friedrich Nietzsche's genealogie.

Pragmatisten zien moraal als een instrument om problemen op te lossen. Als die instrumenten goed werken, zijn we ons ternauwernood bewust dat we ze hanteren. Maar als de problemen veranderen, werken de bestaande instrumenten soms niet langer goed, en pas je dus zo nodig de moraal aan. Van hen leerde ik moraal te begrijpen als een dimensie van onze praktische omgang met een veranderlijke wereld.

Maar instrumenten hang je naast elkaar, rustig, op een rekje. Moraal is daarvoor vaak veel te woest. Zij kan zo woest worden, dat ze zichzelf opvreet, zoals nu met het hedendaagse verbod op moraliseren. In navolging van Nietzsche begrijp 
ik moraal als een dynamisch spanningsveld waarin normen en waarden elkaar beurtelings versterken, ondermijnen, uit de weg gaan, of verschrikkelijk botsen. Hier heersen verscheurdheid, tragiek en vuile handen. Rust is bedrieglijk en wijst eerder op een patstelling dan op een consensus. Moraal is geen instrument dat we na gebruik weggooien. Zij zit diep in ons lichaam en onze ziel verankerd, getuige morele emoties als verontwaardiging, walging, trots, schaamte, spijt, meelijden, of minachting. Daarover hebben we heel weinig controle. Moraal is een deel van het verhaal dat we over onszelf vertellen. Mensen gaan kapot als ze gedwongen worden in te gaan tegen hun diepste morele overtuigingen. Moraal oefent kracht op ons uit. Vaak wuiven we haar appèl achteloos terzijde. Maar op andere momenten maakt ze ons letterlijk misselijk van verontwaardiging. Ze kan ons ook boven onszelf uittillen. En soldaten zonder moraal - moreel - verliezen de strijd. Om deze redenen is morele verandering een veel pijnlijker, gewelddadiger en onvollediger proces dan pragmatisten denken. En daarom hebben niet alleen veel filosofen, maar ook veel gewone mensen er de pest aan.

En de techniek? Dat is de onruststoker die de wankele evenwichten binnen dit morele krachtenveld voortdurend verstoort.

\section{$\underline{\text { Heraclitëische ethiek }}$}

Ethiek moet ons helpen ons te oriënteren in deze dynamische wereld. Ik heb eerlijk gezegd nog maar een vage voorstelling van hoe die ethiek er uit moet komen te zien. Maar ik heb hem al wel gedoopt. Dit wordt - met een knipoog naar Arie Rip, die het ooit had over 'Heraclitean steering - de Heracliteïsche ethiek. Heraclitus is de oude Griekse wijsgeer uit Efeze van wie alleen een paar fragmenten zijn overgebleven - net genoeg om van hem een soort anti-Plato te maken voor wie niet het Zijn maar het Worden primair is. ${ }^{1}$ Aan hem toegeschreven spreuken zijn: Het zijn dezelfde rivieren waar wij in stappen en

\footnotetext{
${ }^{1}$ Of dat terecht is, wordt overigens betwist. Zie het commentaar van Cornelis Verhoeven op Hercalitus' Spreuken, p.104 e.v.
} 
het zijn niet dezelfde; wij zijn het en wij zijn het niet. [Heraclitus (1993). Spreuken. Vertaald, ingeleid en toegelicht door Cornelis Verhoeven. Baarn: Ambo, p.21] Of ook: Oorlog is de vader alles, de koning van alles. [idem] De wereld staat volgens hem bol van de onophefbare spanningen. Met het pragmatisme neemt de Heracliteïsche ethiek haar eigen voorlopige karakter serieus. Zij vraagt altijd in hoeverre de morele antwoorden van hier en gisteren verplaatsbaar zijn naar de vragen van elders en morgen. Met Nietzsche's genealogie, neemt zij strijd en conflict serieus. Zij erkent dat we geen vaste grond onder de voeten hebben maar dat we zelf deel uitmaken van het morele krachtenveld.

\section{Techniek politiek: Ontbrekende democratische instituties}

Ik eindig met de politiek. Als techniek ons bestaan zo diepgaand beïnvloedt, dan moet ze aan democratische controle worden onderworpen. Met veel vallen en opstaan begint dat bij de hard impacts een beetje te lukken. Op voorwaarde dat de gevolgen van techniek a) in cijfers uit te drukken, b) duidelijk schadelijk, en c) louter aan technische gebreken te wijten zijn, dan lukt het soms om techniekontwikkelaars, beleidsmakers en politici ter verantwoording te roepen. We investeren bijvoorbeeld veel tijd, energie en geld om te voorkomen dat een medicijn gevaarlijke bijwerkingen heeft, dat Borssele ontploft, of dat nanodeeltjes het milieu vergiftigen.

Maar het blijkt veel moeilijker om soft impacts op de agenda van techniekmakers, beleidsmakers, of het publiek te krijgen en te houden. Als gevolgen van techniek a) eerder kwalitatief dan kwantitatief zijn, b) als je kunt twisten of het wel echt schadelijk is, of c) als de gevolgen worden veroorzaakt door het gebruik dat van de techniek wordt gemaakt, dan wordt er wel gepraat, maar niets gedaan. Ik noem soft impacts niet 'soft' omdat ze onbelangrijk zouden zijn, maar omdat ze zo worden voorgesteld door de huidige instituties die er nog geen raad mee weten.

Een voorbeeld: hoe meer tijdsbesparende techniek, des te minder tijd houden we over. Ra ra hoe kan dat? ledereen herkent dit probleem. Maar kunnen we ons er 
een brede maatschappelijke discussie over voorstellen? Of Haags beleid? Of dat ingenieurs nu betere technologie gaan ontwerpen? Rechtszaken?

Schadevergoedingen? Verzekeringen? Nee. Bij soft impacts blijven de loketten gesloten. Dan is het allemaal 'individuele keuze' en 'eigen verantwoordelijkheid'. Onze democratische praktijken en instituties zijn niet ontwikkeld voor de problemen van de $21^{\mathrm{e}}$ eeuw. We moeten daarom uitvinden hoe soft impacts wel op de publieke agenda kunnen komen.

Daartoe moet het publiek zich eerst bewust worden van die soft impacts. Een manier om dat te doen zijn de techno-morele vignetten en scenario's die ik samen met collega's en studenten in Twente en Maastricht heb ontwikkeld. Door gebruik te maken van de patronen die ik hiervoor in kaart heb gebracht, kun je op een systematische manier verkennen hoe bijvoorbeeld nanotechnologie en synthetische biologie in de toekomst kunnen leiden tot morele veranderingen. Die vignetten, die bijvoorbeeld via het Internet duizenden mensen hebben bereikt en laten meedenken, maken tastbaar hoe nieuwe technieken ons in ons dagelijkse bestaan kunnen gaan raken. Zodat de burger niet met voldongen feiten wordt geconfronteerd, maar zich kan afvragen: wil ik dat eigenlijk wel? Dragen deze technische plannen inderdaad bij aan een rechtvaardiger samenleving en aan een beter leven?

Ik kom aan het eind.

Voor mijn onderzoek kan ik mij geen stimulerender omgeving voorstellen dan de Faculteit der Cultuur- en Maatschappijwetenschappen van de Universiteit Maastricht. Velen hier doen op hoog niveau onderzoek naar de wisselwerking tussen cultuur, wetenschap en techniek. In Maastricht laten we ons leiden door de vragen, niet door de disciplinaire grenzen.

Ik dank iedereen voor de uiterst hartelijke ontvangst en voor de buitengewoon collegiale manier van samenwerken sindsdien. Rein, jouw volledige toewijding aan de bloei van onze faculteit, werkt zeer aanstekelijk. 
Ik heb in mijn onderzoek altijd de grens tussen filosofie en sociale wetenschappen opgezocht, en voel me dus weer helemaal thuis binnen het onderzoeksprogramma Wetenschap- en Techniekstudies, onder leiding van Wiebe Bijker. Nu ik hier een beetje mijn plaats gevonden heb, zie ik ernaar uit het filosofische onderzoek de komende jaren nog inniger te verbinden met het andere STS-onderzoek. Al lonk ik daarbij tegelijkertijd natuurlijk ook uitdrukkelijk naar de beide andere onderzoeksprogramma's.

Dan de capaciteitsgroep filosofie. Individualisten met vaak al uitgekristalliseerde onderzoeksinteresses, werkzaam binnen de drie verschillende onderzoeksprogramma's. Geen gedeelde kern, wel een coherente groep vanwege, om Wittgenstein te citeren, "een gecompliceerd web van gelijkenissen, die elkaar overlappen en kruisen." We houden allemaal van concepten, zijn niet bang voor normativiteit, halen de geschiedenis van de filosofie er te pas en zo nodig te onpas bij, en vinden het niet erg als de theorie de empirie soms wat vooruitsnelt. Er is meer dat ons bindt: Filosofie die zich niet alleen richt tot vakgenoten maar zich ook engageert met de wereld. En dan nemen we het op voor wat - vaak met een beroep de Rede - wordt gemarginaliseerd: of dat nu armen, dementen, of Aidspatiënten zijn, of emoties, Romantiek, conflict, of verbeelding. Zelfs ressentiment wordt bij ons met een open oog onderzocht, door onze kersverse hoogleraar Politieke Cultuur Sjaak Koenis. Ik ben ervan overtuigd dat we, ondanks al onze diversiteit, een eigen, herkenbare, Maastrichtse stem binnen de filosofie kunnen laten horen, waarmee we niet alleen een wezenlijke bijdrage kunnen leveren aan onderwijs en onderzoek aan deze Faculteit, maar ook aan de meningsvorming daarbuiten. Ik dank jullie allemaal voor jullie open en constructieve opstelling.

Dat ik hier vandaag mag staan, dank ik aan meer mensen dan ik nu kan noemen. Pieter Pekelharing leest al 25 jaar alle filosofie, en wijst mij dan op wat ik moet lezen. Voor één van ons beiden is dit een enorm efficiënte manier van werken. Mijn helaas overleden promotor Lolle Nauta leerde mij mijn eigen ideeën serieus te nemen, en strafte met harde hand wanneer mijn taal weer eens 
onbegrijpelijk en wollig werd. Hij zei dat ik hem daarvoor later dankbaar zou zijn, en Lolle: je had gelijk, dat ben ik. Annemarie Mol liet mij kennis maken met de wondere wereld van Science and Technology Studies. Haar compromisloze onderzoeksdrift is sindsdien een baken voor mij. Aan de hand van Jozef Keulartz, Michiel Korthals en Maartje Schermer verkende ik het pragmatisme, en leerde ik onderzoeksaanvragen schrijven. Hans Achterhuis verdedigde in een verzakelijkende universiteit niet alleen de passie voor de filosofie, maar ook de menselijke verhoudingen. Petran Kockelkoren en Peter Paul Verbeek gaven mij de best denkbare inleiding in de techniekfilosofie, en hun vingerafdrukken zitten overal op het vandaag gepresenteerde model. Arie Rip opende niet alleen veel deuren voor me, maar is vooral de laatste jaren een van mijn meest zowel uitdagende als gulle denkpartners geworden. Dat geldt ook voor Hedwig te Molder, met wie ik het onderscheid tussen hard en soft impacts verken. Dan almost last maar zeker niet least - de collega's en AIO's uit mijn vroegere Twentse onderzoeksgroep 'the Ethics and Politics of Emerging Technologies': Marianne Boenink - met wie ik jarenlang het meest heb samengewerkt - , Simone van der Burg, Federica Lucivero, Dirk Haen, Aimee van Wijnsberghe, Lotte Krabbenburg, Anna-Laura van der Laan, Lise Bitsch, buitenlid Dirk Stemerding, en Katinka Waelbers, met wie ik het afgelopen jaar heb gewerkt aan voorlopers van het vandaag gepresenteerde model. Allen, ik wist niet dat je zo veel plezier kon hebben, en dat het dan toch nog filosofie is. We hebben samen het fenomeen technomorele verandering op de onderzoeksagenda gezet, en het is geweldig te zien hoe ieder van jullie dat nu op haar of zijn eigen wijze uitwerkt. Ik ben erg trots dat het EPET inmiddels een landelijk centrum is en dat we volgend jaar ons eerste internationale congres organiseren over technomorele verandering.

Tot slot. Lieve Mem, er zijn vast weinig moeders die hun kind ooit adviseerden om filosofie te gaan studeren. Ik ben je daarvoor nog steeds dankbaar. Toen mijn hormonen begonnen op te spelen drukte je me bovendien Erich Fromms Liefhebben: een kunst een kunde in handen. Ook al een redelijk ongebruikelijke geste voor een moeder. Toch veel dank, want zwaaiend met dat boek kon ik 
eindelijk indruk maken op dat meisje uit de $4^{\mathrm{e}}$ klas. Liefste Evelien. Dank voor je goede voorbeeld, je onvoorwaardelijke steun, en je humor. 34 jaar geleden schreven we ons eerste Diepe Dingen Boekje. Dat we daar nog maar even lang mee door mogen gaan.

Ik heb gezegd. 